\title{
Use of models in surgical predictability of oral rehabilitations ${ }^{1}$
}

\section{Utilização de biomodelos na previsibilidade cirúrgica de reabilitações orais}

\author{
Ricardo Curcio2, Guilherme Luis Perin3, Israel Chilvarquer4, Maria Lucia Borri5, Sergio Ajzen6 \\ 1. Research performed at Imaging Diagnosis Department, Federal University of São Paulo (UNIFESP), Brazil. \\ 2. PhD, Imaging Diagnosis Department, UNIFESP, Head Neck Surgery, Heliópolis Hospital, São Paulo, Brazil. \\ 3. Private practice, dentist, São Paulo, Brazil \\ 4. Associate Professor, Stomatology Department, Faculty of Odontology, University of São Paulo (USP), Brazil. \\ 5. PhD, Imaging Diagnosis Department, UNIFESP, São Paulo, Brazil. \\ 6. Associate Professor, Imaging Diagnosis Department, UNIFESP, São Paulo, Brazil.
}

\begin{abstract}
Purpose: To evaluate the rehabilitation of edentulous mandibles with osseous integrated implants in immediate loading, using models in reverse planning. Methods: A prospective study was performed on 14 patients with a total of 56 implants placed. It was proposed a technique for the rehabilitation of edentulous mandible with osseous integrated implants of immediate loading, using anatomical replicas derived from computerized tomography scan linked to the rapid prototyping technique of stereolithography in reverse planning, elaborating the definitive fixed prosthesis, with rigid union of the implants on the same day. The patients' mandible models were divided in two groups. In the first one, there were patients with edentulous mandible models and with models elaborated after exodontics procedures (Group 1). In the second (Group 2), patients with dentulous mandible models, which allow an evaluation of difficulty in the surgery. Results: The proposed technique using anatomical models for the personalization of mandibles in immediate loading had $100 \%$ of less difficulty in the adaptation of the surgery guide while the dentulous models had $83,3 \%$ of more difficulty. Conclusion: The proposed technique using the mandible models in the rehabilitation of mandibles is feasible. Key words: Dental Implantation, Endosseous. Mandible. Immediate Loading.
\end{abstract}

\section{RESUMO}

Objetivo: Avaliar a reabilitação de mandíbulas edêntulas com implantes osseointegrados, em função imediata, utilizando biomodelos no planejamento inverso. Métodos: Foi realizado um estudo prospectivo em 14 pacientes com um total de 56 implantes colocados, em que foi proposta uma técnica de reabilitação de mandíbulas edêntulas com implantes osseointegrados, em função imediata, utilizando biomodelos, confeccionados a partir dos dados da tomografia computadorizada, no planejamento inverso, confeccionando a prótese fixa final, com união rígida dos implantes, no mesmo dia. Os biomodelos dos pacientes foram divididos em dois grupos. Um deles composto pelos pacientes com biomodelos edêntulos e aqueles confeccionados após exodontia (grupo 1). O outro (grupo 2) composto pelos pacientes com biomodelos dentados, sendo avaliada a dificuldade do procedimento, quanto a cirurgia. Resultados: A técnica proposta do uso da prototipagem biomédica na função imediata nas mandíbulas com biomodelos edêntulos teve 100,0 \% de menor dificuldade na adaptação da guia cirúrgica, enquanto os biomodelos dentados apresentaram 83,3 \% de maior dificuldade. Conclusão: O biomodelo no planejamento inverso de reabilitações orais teve $100,0 \%$ de menor dificuldade em comparação com os protótipos dentados 83,3\% de maior dificuldade. Descritores: Implante Dentário Endoósseo. Mandíbula. Função Imediata. 


\section{Introduction}

Since Branemark et al.1 and Adell et al.2 published the results of the treatment with fixed prostheses on implants in edentulous mandibles with a 10-year follow up period, getting between $95 \%$ and $98 \%$ of success and helping patients with this revolutionary option of treatment, a paradigm was created. Temporary prostheses present absence of stability and retention, becoming risky and inconvenient to the patient due to inadequate forces performed on them and to the discomfort in their use between 3 and 6 months4-6. On the opposite side, there is the idea of reducing this time of union between bone and implant using fixed prostheses. Studies about it prove that fixed prostheses, with rigid union of implants submitted to masticatory load after their placement, show encouraging results3,4,6-16. Considering new reality, we developed this research, due to the necessity of a higher surgical predictability in this treatment. With advance of computerized tomography (CT), which is a precise complementary exam, tomographic cross-sectional images provide the surgeon with a better visibility of the anatomical situation of the evaluated site in the diagnosis and treatment planning, allowing a planning that offers more predictability and security 17,18 . We applied prototyping allied to osseous integrated implants, computerized technology progress and medical images processing in this new treatment proposal. Biomedical prototyping is based on the use of physical models (biomodels), which are generated from virtual surroundings, allowing the simulation of surgeries and prosthetic rehabilitations 18,19. Preliminary studies suggest that modelling of anatomical structures of maxilla and mandible through biomedical prototyping, using data from computerized tomography, is a technique that can be applied in implants surgical planning and in Anatomy teaching20. Therefore we limit our work proposal to models in inverse planning of immediate loading in edentulous mandibles, specifically in their great use in surgery predictability.

\section{Methods}

In this prospective clinical study, the casuistic was composed by fourteen healthy patients from a private clinic from São Paulo, Brazil, who are edentulous or partially dentulous in mandible and willing to have the mandible total rehabilitation with osseous integrated implants in immediate loading. All patients were fully informed about benefits and hypothetical risks of implants immediate loading, as well as treatment alternative options. This study was approved by UNIFESP Ethics in Research Committee (Comitê de Ética em Pesquisa da UNIFESP) and all 196/96 Resolution demands were respected. The computed tomography was performed using a helical unit Select SP, Picker, following the conventional technical specifications with production of rapid prototyping model: helical volumetric acquisition of all mandible until mandibular condiles (patient with slightly open mouth), and occlusal plan parallel to tomographic cross section line. It was generically used $120 \mathrm{KVp}$ and $90 \mathrm{~mA}$, section thickness of $1,5 \mathrm{~mm}$ and average capture time of thirty and sixty seconds. Axial sections were made with 1,0 $\mathrm{mm}$ of thickness obtained through helical technique, with parallel direction to occlusal surfaced followed of orthogonal and panoramic refformatation alongside alveolar processes axis. Reconstructions were $2 \mathrm{~mm}$ far from each other (Figures 1 - 4). The complete exam was sent to BioParts, in Brasilia, where images were segmented to separate soft tissue from osseous structure. The last one was used to refformat the model final geometry. The production of models through biomedical prototyping was the construction process of physical models of human anatomy through rapid prototyping techniques from a CAD system (computeraid assisted), allowing the morphological duplication of anatomical structures in real scale of $1: 1$, obtained through CT. These models were based on patients' computerized tomographies. Images were analysed on a video terminal and recorded in CDs. Then, they were sent to BioParts Laboratory, where the production of models was made through a rapid prototyping system, representing the anatomical structure accurately. The production of models was made through 3D Printer manufacture mechanism - layers of powder material. A roller distributed and compressed the powder (Figure 5) from the table of manufacture chamber.

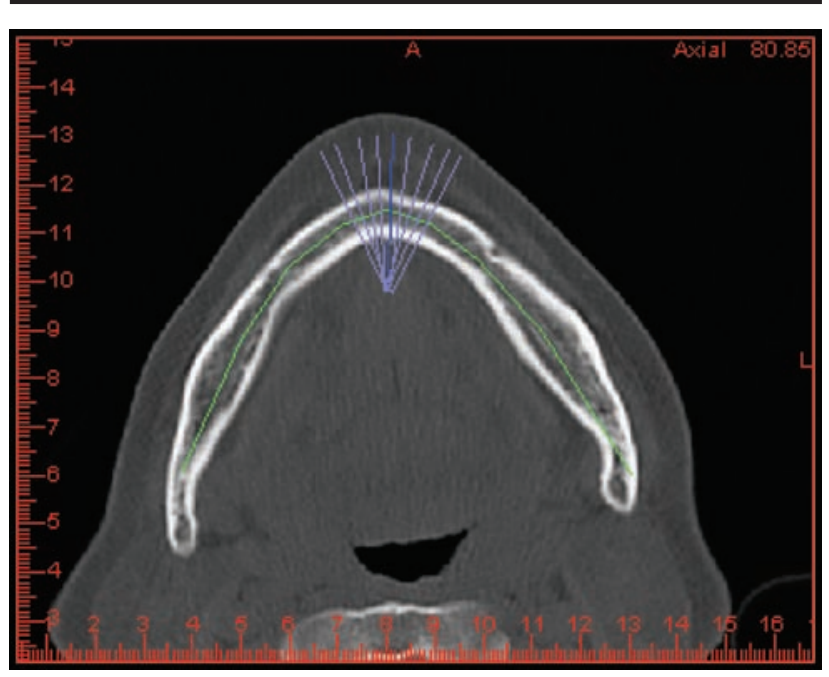

FIGURE 1 - Mandible axial section made in the Dental Slice software

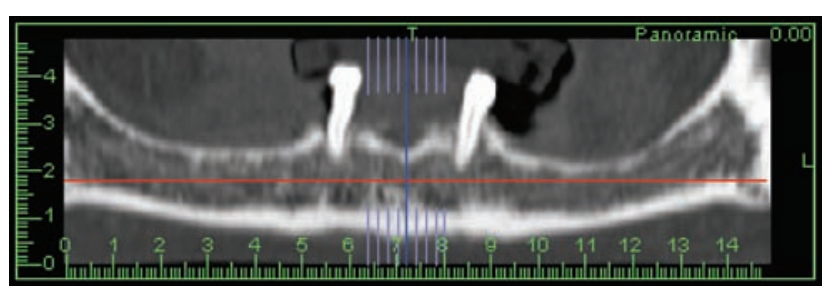

FIGURE 2 - Mandible panoramic section made in the Dental Slice software 


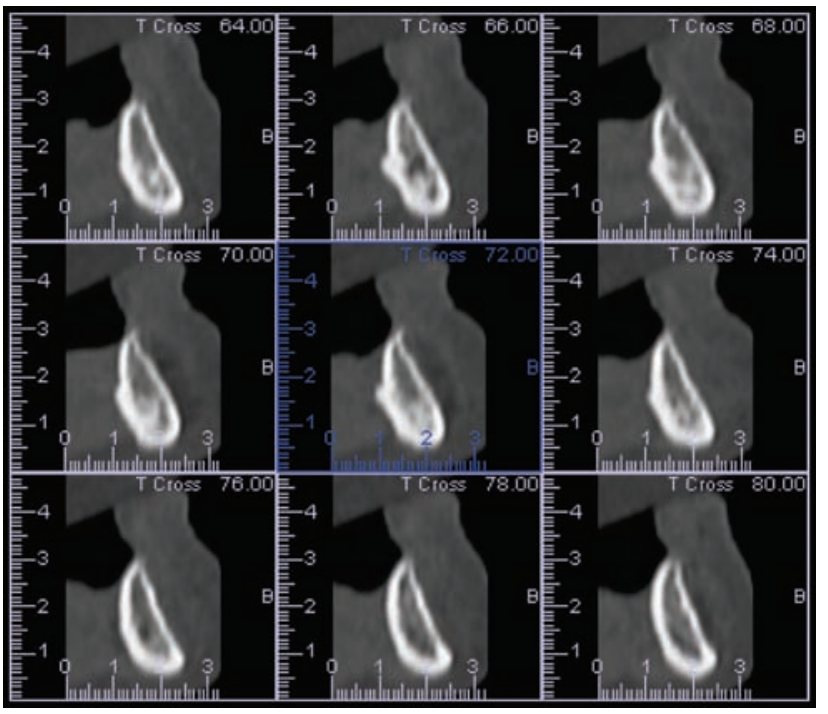

FIGURE 3 - Mandible tomographic section made in the Dental Slice software

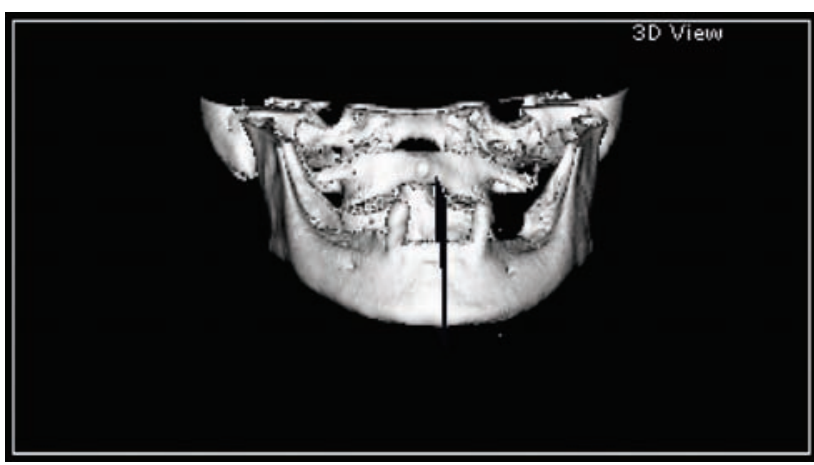

FIGURE 4 - Mandible three-dimensional reconstruction made in the Dental Slice software

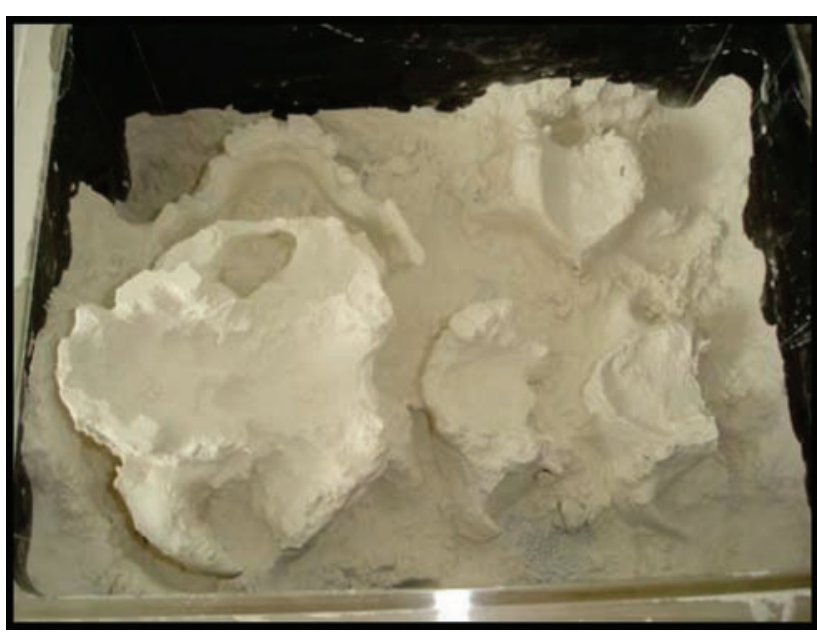

FIGURE 5 - Prototypes after the production, in the machine, without finishing
These $0,1 \mathrm{~mm}$ thick layers were agglutinated one after the other. Therefore, the final result was a mandible model of average accuracy of about $0,43 \mathrm{~mm}$ (Figure 6). As in the whole process one layer was on the other, there were no geometry limit that could not be prototyped. So, internal structures were also reproduced. Images were manipulated through a specific software, which presents basic function for processing and conversion of files into necessary images. CT files represented two-dimensional sections saved in Dicom format, but, in order to produce a model, three-dimensional files in prototyping standard STL format (Printer 3D) are necessary. Partially dentulous patients had the remaining mandibular teeth extracted before the tomography, when they presented infection or metallic prosthesis, due to distortion caused in the production of the model. After extraction of remaining inferior teeth, it was produced an immediate total prosthesis, which was placed on the day of the extraction with necessary adjustment, restoring the patients' vertical dimension. Inferior immediate total prostheses or total prostheses of mandibular edentulous patients or dentulous model were used in the transfer of the prototype to the articulator, all of them with bite register (Figure 7).

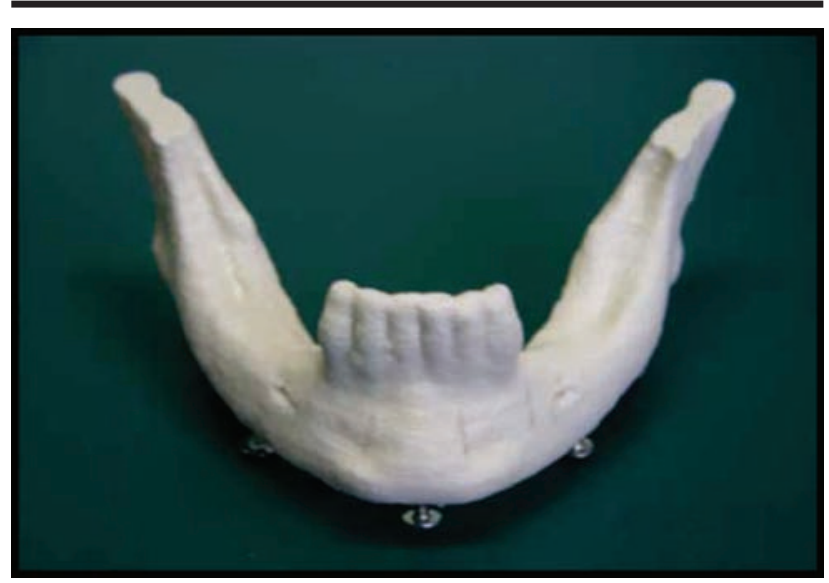

FIGURE6-Dentulousmodelproducedbyrapidprototyping

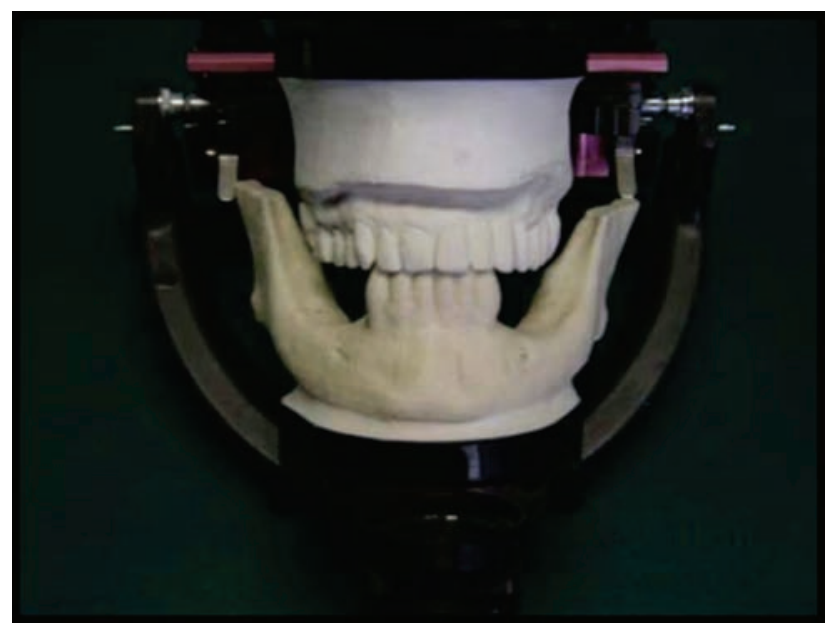

FIGURE 7 - Dentulous model transferred to the articulator 
The surgical guide was made after placement of four implant replicas in the mentum region of the model. Acrylic resin with titanium cylinders of two and $3 \mathrm{~mm}$ of diameter by 10 and $9 \mathrm{~mm}$ of height and $0,5 \mathrm{~mm}$ of thickness were used. The cylinders should fit in one on another in relation to the placed replicas in the model, respecting the spaces for surgical burs in progressive drills, in order to obtain plentiful irrigation during surgery. The distal part of the surgical guide was designed as a cell on the mandibular osseous crest of the model, with extensions in vestibular face of the guide to be fixed and stabilized on the patient's mandible (Figure 8).

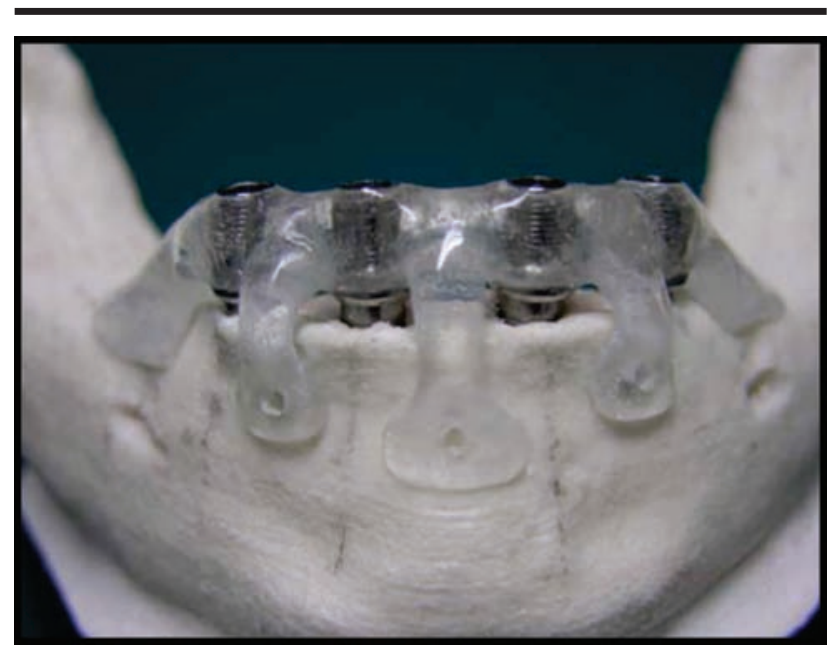

FIGURE8-Surgicalguideproducedonfourimplantsreplicas

Inverse planning was executed in the patient's prosthetic preparation through a new waxing and teeth assembling on the model, which was previously acrylized. The main parameter was the necessary space for the production of rigid metallic bar. Therefore, teeth assembling was preestablished while superior model was kept in the articulator in the defined vertical dimension. After definition of the space between teeth and artificial gum, waxing of metallic bar screwed on implants was made. Prosthetic components like UCLA (Connection Prostheses and Implants System, São Paulo, Brazil) cast with NiCrTi alloy (nickel chromium titanium), which was later segmented in four parts, were used for laser welding on the surgery day. A crestal supra incision to the queratinized gum level was made, leaving the same quantity of tissue with these characteristics by vestibular and lingual. Size of incision was defined according to size of surgical guide, for its placement without tension in osseous tissue. Flap removal was made by vestibular and lingual for wide visibility of the mandible anterior region. After exposure of the anterior region of the mandibular bone, surgical guide placing and its fixation with 1,8 $\mathrm{mm}$ diameter screws (Connection Prostheses and Implants System, São Paulo, Brazil) in anterior vestibular region was made to stabilize it. When patients were dentulous, firstly they had their teeth extracted, then there was radicular alveolus curettage and plentiful washing with aqueous iodine added to 0,9\% physiologic serum. After cleaning, there was region osteoplasty for the surgical guide adaptation, which had cell-shape distal extensions as main reference. Fixation was made with 1,8 mm diameter screws (Connection Prostheses and Implants System, São Paulo, Brazil). Serial drills were started with lance-shaped bur, then $2 \mathrm{~mm}$ bur and, $3 \mathrm{~mm}$ bur to finalize them. The burs were always put in surgical guide with their respective guide tubes of 2 and $3 \mathrm{~mm}$ of diameter with plentiful irrigation of physiologic serum. Counter sink last bur was not used for a better implant primary stability. The purpose of drilling technique was to maximize primary stability with osseous compression through subpreparation of the bone. Due to concept of high primary stability, this study was based on radiographic and clinical diagnosis of bone quality, on the use of appropriate technique of preparation the receptor bone and on the right choice of implant type. The first drill of osseous cortical was determined with a lance-shaped drill. Then, a $2 \mathrm{~mm}$ spiral-shaped drill was used, indicating implant length. Four LTX external hexagon cylindrical implants (3i, West Palm Beach, Fl, USA) were placed. We did not use implants, whose height and thickness are smaller than $13 \mathrm{~mm}$ and 3,75 mm respectively. An-at-least-2-mm security zone between the most distal implants and the mandibular canal was respected. This zone was preestablished in the guide when implants were put in models. Torque was verified by indication in the drilling engine and implants placement (35 Ncm). Cylinder wrench was always used to finalize implants placement. After it, sterilized prosthetical bar segments were screwed and small adjustments in welding interface were necessary. Then, interfaces were united with acrylic resin (Pater resin). Sterile prosthesis bur was used for metallic structure adjustment. After union, previously acrylized teeth were tested and so metallic structure was removed. Four healing caps of $5 \mathrm{~mm}$ of height and $5 \mathrm{~mm}$ of diameter were put before suture with Vicryl 4-0 was made. The patient was taken to a comfortable room to wait for lab procedures. Four implant analogous were put in metallic structure simultaneously for the production of the model and laser welding. Metallic structure united with acrylic resin was removed and sent for laser welding to Prostheses Laboratory (Proden, São Paulo, capital) in a cast transfer model with implant analogous (Figure 9). The patient rested while welding was being made. The model was transferred to the articulator. It gets finished with teeth union, which was made with photopolymerizable acrylic resin (Versyo. Com. Kulzer). Lab work was finalized with prosthesis polishing and, the total work, with occlusal adjustments after the placement in the mouth (Figure 10). The models of the patients were divided in two groups. In group 1, there were patients with edentulous models and models produced after extraction. In group 2, there were patients with dentulous ones. Surgical difficulty was evaluated by the surgeon who operated all patients. It was considered less surgical difficulty when adaptation of the 
surgical guide in the surgery was good, and, more difficulty when adaptation was bad. Fisher test (significance level) was used to compare proportion of surgical and prosthetic difficulty besides kinds of prototypes.

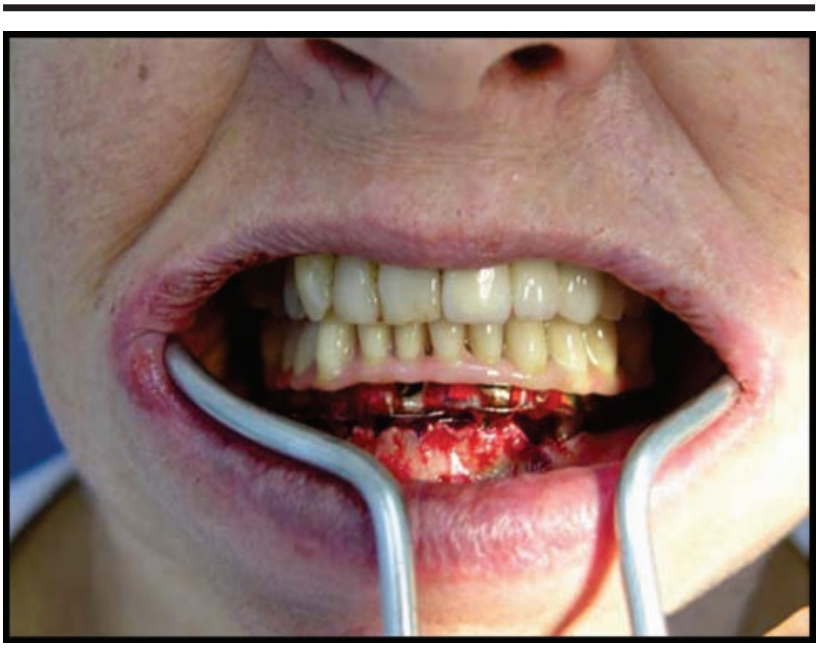

FIGURE 9 - Test of teeth on the infra-structure

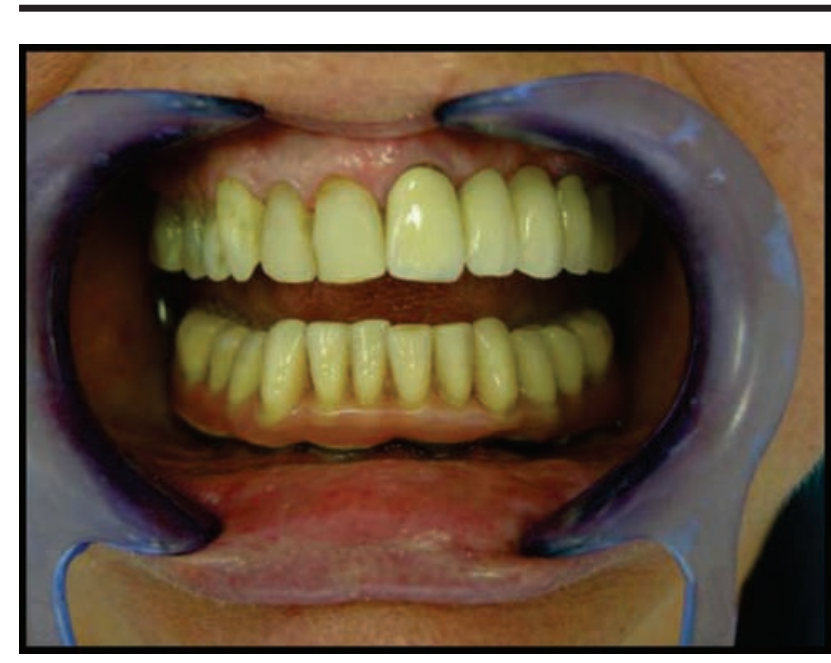

FIGURE 10 - Definitive prosthesis placed in the mouth

\section{Results}

In this study, from fourteen patients who underwent the treatment proposal of immediate loading in edentulous mandibles, four were men and 10 were women. Ages varied between 44 and 84 years old, with average of 61,8 and medium of 62,5 years old. 8 patients had edentulous or after extraction prototypes and 6 patients had dentulous ones. 56 implants of 3i LTX System (3i Innovations, Loma Linda, USA) were placed in the region between mandible mentum foramen (4 to each patient). The placed implants varied between $4 \mathrm{~mm}$ and 3,75 mm of diameter and from $13 \mathrm{~mm}$ to $15 \mathrm{~mm}$ of length. It took $71,5 \%$ of the patients between 7 and 8 hours to be treated, with $64,3 \%$ of less surgical difficulty (Table 1). There was a statistically significative difference in surgical difficulty in relation to the kind of prototype. $83,3 \%$ of more difficulty was observed in dentulous prototypes ( $0 \%$ x 83,3\%; $\mathrm{p}=0,003)$ (Table 2$)$. In the evaluation after 4 months and after 1 year, none of the 14 placed prostheses needed to be replaced, what means, $100 \%$ of success. There were not problems such as pain, swollen, persistent discomfort, neuralsensorial disturbance or postoperative infection in this study (Figure 11).

TABLE 1 - Number and percentage of patients according to time and surgical difficulty

\begin{tabular}{lccc}
\hline VARIABLE & CATEGORY & no. & \% \\
\hline \multirow{2}{*}{ Time / hours } & 7 & 4 & 28,6 \\
& 8 & 6 & 42,8 \\
\hline Surgical Difficulty & 10 & 4 & 28,6 \\
& Less & 9 & 64,3 \\
& More & 5 & 35,7 \\
\hline & Total & $\mathbf{1 4}$ & $\mathbf{1 0 0 , 0}$ \\
\hline
\end{tabular}

TABLE 2 - Number and percentage of patients according to surgical difficulty and kind of prototype

Kind of Prototypes

\begin{tabular}{|c|c|c|c|c|c|c|}
\hline \multirow[t]{2}{*}{ Difficulty } & \multicolumn{2}{|c|}{ Edentulous + after extraction } & \multicolumn{2}{|c|}{ dentulous } & \multicolumn{2}{|c|}{ Total } \\
\hline & no. & $\%$ & no. & $\%$ & no. & $\%$ \\
\hline Less & 8 & 100,0 & 1 & 17,7 & 9 & 64,30 \\
\hline More & - & - & 5 & 83,3 & 5 & 35,70 \\
\hline Total & 8 & 100,0 & 6 & 100 & 14 & 100,00 \\
\hline
\end{tabular}

$\mathrm{P}($ Fisher Test $)=0,003$ 


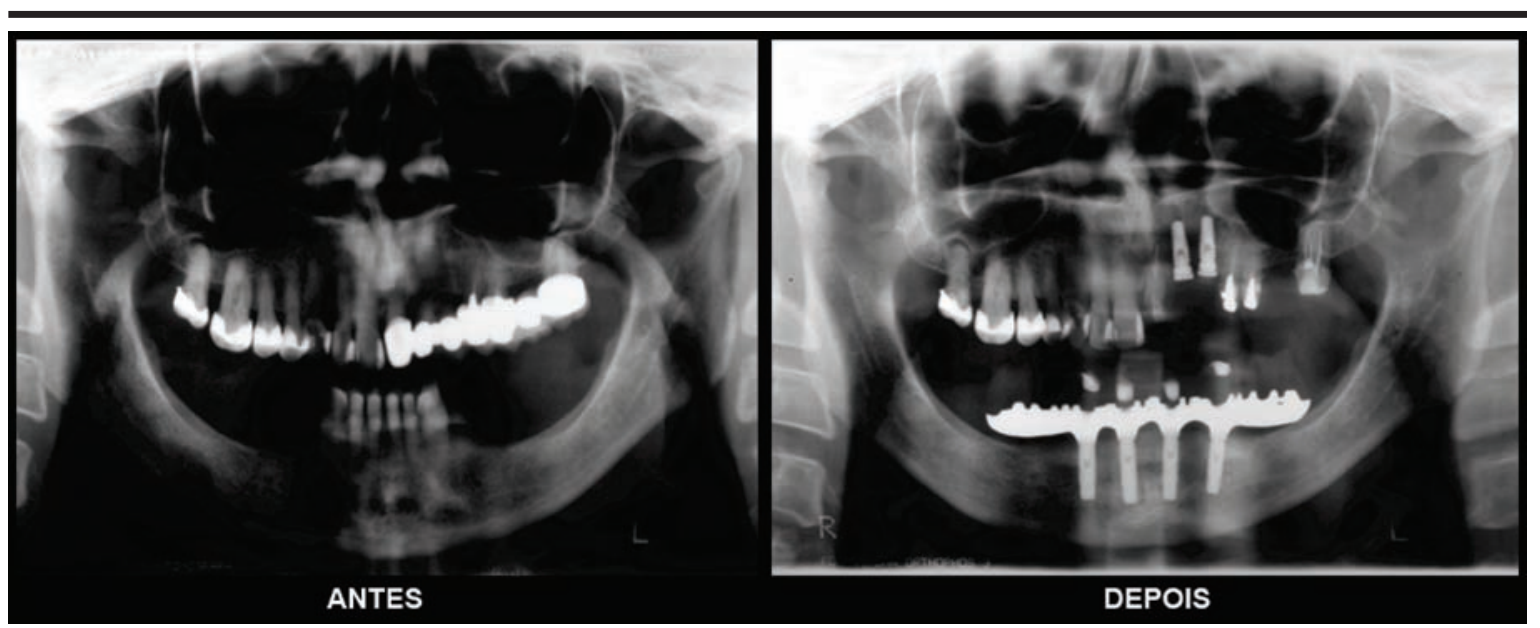

FIGURE 11 - Preoperative panoramic radiography and 4-month panoramic radiography

\section{Discussion}

Tooth and alveolar osseous loss besides the consequent need of using prostheses can affect the patient's sociability. They also make mastication difficult and develop digestion problems and non-use of proteins, which weaken the patients even more, mainly the elderly ones. Half of our casuistic is about elders, who are between forty-four and 84 years old, presenting an average of 61,8 years old and medium of 62,5 years old21. Rehabilitation of edentulous inferior arch having the support of osseous integrated implants and, with the traditional protocol of two surgical stages, has showed good results. However, the waiting period of three to four months in the mandible needing the production of temporary removable prostheses makes the patients' adaptation difficult. These prostheses often do not have stability and retention, what causes discomfort and need of frequent adjustment besides psychological and social problems3,4,5,22. Immediate loading was developed aiming at the patient's comfort, treatment time reduction and, consequently, cost reduction as well. In our study, 56 implants were placed, which 28 were $13 \mathrm{~mm}$ long and 28 were $15 \mathrm{~mm}$ long, all of them in the region between mentum foramen. In a study about eight patients without posterior teeth on both sides, with the purpose of establishing clinical criteria of osseous quality and primary stability, Tortamano Neto et al.23 concluded that two implants united to each other are enough to obtain the primary stability. In our study, we used 56 LTX implants with the same surface treatment and also the $3 \mathrm{i}$ implants system (3i Innovations, Palm Beach, Fl, USA). According to Engstrand et al.2426, the proposal of Branemark Novum System is a production technique of a prefabricated definitive fixed prosthesis in immediate loading that is placed on the day of the surgery. That brings the following advantages: treatment time considerable reduction and fewer appointments if compared to two-stage protocol. In the diagnosis and treatment planning with computerized tomography aid, the visibility of tomographic cross-sectional images provide the surgeon with a better predictability of the anatomical situation of the evaluated site, allowing a secure planning. This program allied to rapid prototyping permitted a presurgical planning that is very similar to the final rehabilitation, giving to the surgeon more time during surgical procedure and production of the final prosthesis 18,27. In our study, tomographies were made by a helical computerized tomographer, whose advantage is a reduced mobility time. As images are obtained without movement, they have a very high quality19. We see prototyping allied to osseous integrated implants, computerized technology progress and medical images processing providing the modelling of anatomical structures of maxilla and mandible with application in surgical planning of implants18. According to Mazzonetto et al.20, the stereolithographic models, produced from data obtained through CT, magnetic ressonance or scanner by laser, make possible the production of anatomical structures models. Diagnosis, planning and surgical simulation that use models exist already in oral and maxillofacial surgery. Moreover, we want to point out the importance of these models to the patients, who had precise idea about the proposed treatment. Their awareness was something notable in our study. D'Urso et al.28 have already concluded that models help surgeons to rehearse the procedures and improve communication between them and their patients. The use of stereolithography in oral and maxillofacial surgery showed advantages related to the representation of anatomical structures model: precision and sterilization of stereolithographic prototypes for intraoperative use. It also confirmed better predictability, improved operative results, decreased risks and shortened surgical time29-31. In our study, the models were made through rapid prototyping, which is different from stereolithography. This one is a new technology that can produce physical models hardening selectively a UV-sensitive liquid resin using laser-beam. It reproduces the real anatomical maxillary and mandibular dimensions. With these models, it is possible to fabricate surgical guides, which can place the implants "in vivo" at 
the same sites and directions previously simulated in the computer. Rapid prototyping grants more fragile characteristics to the model. However, we did not face any problem in drilling it to place the implant replicas. Lack of transparency is another disadvantage of rapid prototyping compared to stereolithography method. But, in the first one, mentum foramen were very visible, preserving the results. Sammartino et al.32 presented a case report of a patient with mandibular atrophy, who was rehabilitated with an overdenture supported by two Branemark implants. Two different surgical planning methods were taken into account: the production of surgical guide considering clinical aspects and surgical guide built on the model. We agree with the authors that surgical planning based on stereolithographic model is a safe procedure and has many advantages. This technological advance offers biological and therapeutical benefits because simplifies the surgicalanatomical handling, improving the implant placement. But, we also agree with Sarment et al.33, who affirmed that the stability of surgical guide is difficult when the model presents teeth and, in edentulous regions or in edentulous mandibles, the guide adapts itself better on osseous support. Our results showed less difficulty in adapting the surgical guide on the 8 edentulous prototypes $(100 \%)$. With the use of a high resolution images capture protocol, we could notice that the difference between the model and the bone was insignificant18. In our study, we had less difficulty in the 8 surgical guide placement $(100 \%)$ when models were edentulous or had remaining teeth extracted. When models were dentulous needing extraction and osseous planning, not only in the models but also in the surgery, we had more difficulty in the 5 surgical guide adaptation (83,3\%). However, it is important to point out that in both cases the guides kept their position through their distal extensions. Treatment proposal was not prohibitive at any time. Predictability became an important factor when we want to finish the treatment on the same day. In literature we find studies that show placement of temporary fixed prostheses on edentulous mandibles on the same day $3,4,6,9,12,13,22,34,35$. Branemark et al.39 definitive prostheses were placed in immediate loading on the same day, proving that predictability was decisive. Morton et al.37 discussed previous planning, which surgical guide would be another predictability factor in immediate loading. Surgical guide also makes the final result different when it is closely produced to real situation. As we could observe, diagnosis technological progresses not only increased strategical possibilities in the planning of implantological surgeries with immediate loading, but also made surgeries more predictable, shortening surgical time considerably19. Regarding to immediate loading execution time, it took us from seven to 10 hours, with time reduction as cases were being executed. Nowadays, cybernetics allows us to send tomographic digital data through Internet and to receive a three-dimensional anatomical model. It allows us to convert a digital image from a digital camera or conventional Cad/ Cam into a physical object, that reproduces the sent information precisely19. We find many studies in the literature discussing the application of these sophisticated techniques, which surgical guide is produced through Cad/ Cam system and many companies and universities are involved38-42. Although this kind of guide demands high cost and elaboration time, it also represents a great time reduction and an useful aid during surgery. There are three ways of producing these guides: directly on the model (used in our study); from an axial computerized tomography obtained with presurgical guide with teeth of radio-opaque material; or from a dynamic axial tomography with planning being executed through specific softwares (SimPlant, SimPlant planner, Materialise). We think information technology has no boundaries for its evolution. However, we must point out that professional experience and good education in oral implantology is essential to execute immediate loading and to evaluate the patient. He is the person, who has to be entirely evaluated through detailed clinical diagnosis and specific radiographic diagnosis with three-dimensional images of osseous configuration in the implants placement zone. All of it allied to advances that allow the production of surgical guides, which are extremely important because help us to transport the implants positions to the patient's mouth during surgery. This procedure happens exactly as it was planned on the models of diagnosis, simulating the surgery and the patient's definite rehabilitation. In the future, it will be easier to access all this technology and, consequently, treatments will have more predictability.

\section{Conclusion}

The model in the reverse planning of oral rehabilitations had $100 \%$ of less difficulty compared to dentulous prototypes, which had $83,3 \%$ of more difficulty.

\section{References}

1. Branemark P-I, Hansson BO, Adell R, Breine U, Lindstrom J, Hallén $\mathrm{O}$ et al. Osseointegrated implants in the treatment of the edentulous jaw: experience from a 10yearperiod. Scand J Plast Surg. 1977;16(Suppl):1-132.

2. Adell R, Lekholm U, Rockler B, Branemark P-I. A 15year study of osseointegrated implants in the treatment of edentulous jaw. Int J Oral Surg. 1981;(6):387-416.

3. Schnitman PA, Wohrle PS, Rubenstein JE, DaSilva JD, Wang NH. Ten-year results for Branemark implants immediately loaded with fixed prostheses at implant placement. Int J Oral Maxillofac Implants. 1997; 12:495-503.

4. Tarnow DP, Emtiaz S, Classi A. Immediate loading of threaded implants at stage 1 surgery in edentulous arches: ten consecutive case reports with 1-to 5-year data. Int J Oral Maxillofac Implants. 1997;12:319-24. 
5. Hildebrand D, Kunz A, Mehrhof J, Nelson K. Immediate loading of implants in edentulous jaws: a series of cases reports. Int J Oral Maxillofac Surg. 2001;30:S14.

6. Balshi TJ, Wolfinger GJ. Immediate loading of Branemark implants in edentulous mandibles: a preliminary report. Implant Dent. 1997;6(1):83-8.

7. Horiuchi K, Uchida H, Yamamoto K, Sugimura M. Immediate loading of Branemark system implants following placement in edentulous patients: a clinical report.IntJOralMaxillofacImplants.2000;15(6):824-30.

8. Jaffin RA, Kumar A, Berman CL. Immediate loading of implants in partially and fully edentulous jaws: a series of 27 cases reports. J Periodontol. 2000;71(5):833-38.

9. Chow J, Hui E, Liu J. Immediate loading of Branemark system fixtures in the mandible with a fixed provisional prosthesis. Appl Osseointegration Res. 2001;1(1):30-5.

10. Colomina LE. Colocação imediata de implante fixo de prótese mandibular: um aguardado estudo clínico de 18 meses de acompanhamento. Implant Dent. 2001;10:23-9.

11. Ganeles J, Rosenberg MM, Holt RL, Reichman LH. Immediate loading of implants with fixed restorations in the completely edentulous mandible: report of 27 patients from a private practice. Int J Oral Maxillofac Implants. 2001;16(3):418-26.

12. Cooper LF, Rahman A, Moriarty J, Chaffee N, Sacco D. Immediate mandibular rehabilitation with endosseous implants: simultaneous extraction, implant placement, and loading. Int J Oral Maxillofac Implants. 2002; 17:517-25.

13. Testori T, Del Fabbro M, Szmukler-Moncler S, Francetti L, Weinstein RL. Immediate occlusal loading of osseotite implants in the completely edentulous mandible. Int $\mathrm{J}$ Oral Maxillofac Implants. 2003;18(4):544-51.

14. Misch CM. Immediate loading of definitive implants in the edentulous mandible using a fixed provisional prosthesis: the denture conversion technique. J Oral Maxillofac Surg. 2004;62(9 Suppl 2):106-15.

15. Testori T, Del Fabbro M, Galli F, Francetti L, Taschieri S, Weinstein R. Immediate oclusal loading the same day after implant placement: comparison of 2 different time frames in totally edentulous lower jaws. J Oral Implantol. 2004;30(5):307-13.

16. Aalam AA, Nowzari H, Krivitsky A. Functional restoration of implants on the day of surgical placement in the fully edentulous mandible: a case series. Clin Implant Dent Relat Res. 2005;7(1):10-6.

17. Chilvarquer I. A radiologia e seus avanços contemporâneos. Rev Assoc Paul Cir Dent. 1993;47(2):1001-4.

18. Chilvarquer I, Chilvarquer LW, Hayek JE. A esteriolitografia na implantodontia avançada: conceitos, indicações e usos. Implant News. 2004;1:69-72.
19. Bechelli AH. Carga imediata em implantologia oral: protocolos diagnósticos, cirúrgicos e protéticos. Casos clínicos. São Paulo: Livraria Santos Editora; 2006.

20. Mazzonetto R. Moreira RWF, Moraes M, AlbergariaBarbosa JR, Passeri LA, Spagnoli DB. Uso de biomodelos estereolitográficos em cirurgia buco maxilo facial. Rev Assoc Paul Cir Dent. 2002; 56(2):115-8.

21. Souza Pinto AV. Avaliação clínica e radiográfica de implantes osseointegráveis na mandíbula posterior e submetidos a um protocolo de função oclusal precoce [Tese-Doutorado].Araçatuba:FaculdadedeOdontologia da Universidade Estadual de São Paulo; 2004.

22. Randow K, Ericsson I, Nilner K, Petersson A, Glantz PO. Immediate functional loading of Branemark dental implants: an 18-month clinical follow-up study. Clin Oral Implants Res. 1999;10(1):8-15.

23. Tortamano Neto P, Camargo LOA, Veiga JL. Critérios clínicos de estabilidade inicial e qualidade óssea para o carregamento imediato de implantes osseointegrados. Implant News. 2004;1(1):61-6.

24. Engstrand P, Nannmark U, Martensson L, Galéus I, Branemark PI. Branemark Novum: prosthodontic and dental laboratory procedures for fabrication of a fixed prosthesis on the day of surgery. Int J Prosthodont. 2001;14(4):303-9.

25. Engstrand P, Grondahl K, Ohrnell LO, Nilsson P, Nannmark U, Branemark PI. Prospective follow-up study of 95 patients with edentulous mandibles treated according to the Branemark Novum concept. Clin Implant Dent Relat Res. 2003;5(1):3-10.

26. Henry PJ, van Steenberghe D, Blomback U, Polizzi G, Rosenberg R, Urgell JP. Prospective multicenter study on immediate rehabilitation of edentulous lower jaws according to the Branemark Novum protocol. Clin Implant Dent Relat Res. 2003;5(3):137-42.

27. Curcio R, Perin GL, Chilvarquer I, Borri ML, Ajzen $\mathrm{S}$. Planejamento reverso com estereolitografia em carga imediata em mandíbula edêntula: nota técnica. Implant News. 2005;2(4):377-82.

28. D’Urso PS, Barker TM, Earwaker WJ, Bruce IJ, Atkinson RL, Lanigan MW. Stereolithographic biomodelling in craniofacial surgery; a prospective trial. J Cranio Maxillofac Surg. 1999;27:30-7.

29. Arvier JF, Barker TM, Yau YY, D’Urso PS, Atkinson RL, McDermant GR. Maxillofacial biomodelling. Br J Oral Maxillofac Surg. 1994;32(5):276-83.

30. Bill JS, Reuther JF, Dittmann W, Kubler N, Meier JL, Pistner H, W. Stereolithography in oral and maxillofacial operation planning. Int J Oral Maxillofac Surg. 1995;24(1 Pt 2):98-103.

31. Bouyssié JF, Bouyssié S, Sharrock P, Duran D. Stereolithographic models derived from x-ray computed tomography: Reproduction accuracy. Surg Radiol Anat. 
1997;19(3):193-9.

32. Sammartino G, Della Valle A, Marenzi G, Gerbino S, Martorelli M, di Lauro AE, di Lauro F. Stereolithography in oral implantology: a comparison of surgical guides. Implant Dent. 2004;13(2):133-9.

33. Sarment DP, Sukovic P, Clinthorne N. Accuracy of implant placement with a stereolithographic surgical guide. Int $\mathrm{J}$ Oral Maxillofac Implants. 2003;18(4):471-7.

34. Chee W, Jivraj S. Efficiency of immediately loaded mandibular full-arch implant restorations. Clin Implant Dent Relat Res. 2003;5(1):52-6.

35. Maló P, Rangert B, Nobre M. “All-on-four” immediatefunction concept with Branemark System implants for completely edentulous mandibles: a retrospective study. Clin Implant Dent Relat Res. 2003;5(1):2-9.

36. Branemark PI, Engstrand P, Ohrnell LO, Grondahl K, Nilsson P, Hagberg K, et al. Branemark Novum: a new treatment concept for rehabilitation of the edentulous mandible: preliminary results from a prospective clinical follow-up study. Clin Implant Dent Relat Res. 1999;1:2-16.

37. Morton D, Jaffin R, Weber HP. Immediate restoration and loading of dental implants: clinical considerations and protocols. Int J Oral Maxillofac Implants. 2004; 19:103-8.

38. Benjamin L S. The evolution of multiplanar diagnostic imaging: predictable transfer of preoperative analysis to the surgical site. J Oral Implantol. 2002;28(3):135-44.

39. Van Steenberghe DV, Naert I, Andersson M, Brajnovic I, Cleynenbreugel JV, Suetens P. A custom template and definitive prosthesis allowing immediate implant loading in the maxilla: a clinical report. Int $\mathrm{J}$ Oral Maxillofac Implants. 2002;17:663-70.

40. Tardieu P, Vrielinck L, Escolano E. Computer-assisted implant placement: a case report: treatment of the mandible. Int J Oral Maxillofac Implants. 2003;18:599604.

41. Casap N, Tarazi E, Wexler A, Sonnenfeld U, Lustmann J. Intraoperative computerized navigation for flapless implant surgery and immediate loading in the edentulous mandible. Int $\mathrm{J}$ Oral Maxillofac Implants. 2005;20(1):92-8.

42. Di Giacomo GAP, Cury PR, Araújo NS, Sendyk WR, Sendyk CL. Clinical application of stereolithographic surgical guides for implant placement: preliminary results. J Periodontol. 2005; 76(4):503-07.

\section{Correspondence:}

Ricardo Curcio

R. Dr. Diogo de Faria, 1087/205

04037-003 São Paulo - SP Brazil

Phone: (55 11)5571-7022

curcio@oralteam.com.br
Conflict of interest: none Financial source: none

Received: April 10, 2007

Review: June 12, 2007

Accepted: July 16, 2007

\section{How to cite this article}

Curcio R, Perin GL, Chilvarquer I, Borri ML, Ajzen S. Use of models in surgical predictability of oral rehabilitations. Acta Cir Bras. [serial on the Internet] 2007 Sept-Oct;22(5). Available from URL: http://www.scielo.br/acb 